\title{
Erratum zu: Écrits sur le système pénitentiaire en France et à l'étranger (Schriften über das Gefängniswesen in Frankreich und im Ausland)
}

Norbert Campagna

\section{Erratum zu:}

\section{Kapitel 6 in: N. Campagna et al. (Hrsg.), Tocqueville-Handbuch, https://doi.org/10.1007/978-3-476-05754-9-6}

Im Kapitel 6, „Écrits sur le système pénitentiaire en France et à létranger (Schriften über das Gefängniswesen in Frankreich und im Ausland)", befand sich auf den Seiten 39 bis 41 fälschlicherweise das Unterkapitel 6.3 („Die ideologische Entgleisung der Ereignisse“), das im Redaktionsprozess versehentlich verdoppelt und aus dem Kapitel 4, „L’Ancien Régime et la Révolution (1856) (Der alte Staat und die Revolution)“, hierher verschoben wurde. 